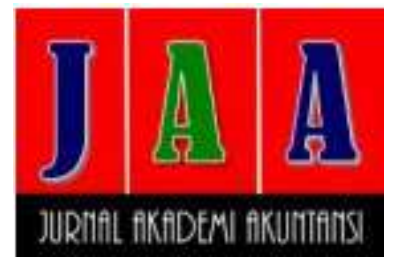

Diterima : 12 April 2019

Direview : 15 April 2019

Direvisi : 17 Mei 2019

Diterima : 20 Mei 2019

Artikel ini tersedia di website

http://ejournal.umm.ac.i

d/index.php/jaa

\section{PENGARUH PENERAPAN SELF ASSESSMENT SYSTEM, PENGETAHUAN WAJIB PAJAK, DAN KUALITAS PELAYANAN TERHADAP KEPATUHAN WAJIB PAJAK (Studi pada Wajib Pajak Orang Pribadi Non Karyawan di KPP Pratama Ciamis Tahun 2017)}

\author{
Irna Liani Putri Anjanni*, Dini Wahjoe Hapsari, Ardan Gani Asalam \\ Program Studi Akuntansi, Fakultas Ekonomi dan Bisnis, Universitas Telkom \\ Jalan Telekomunikasi Terusan Buah Batu Bandung \\ *Corresponding author : irnalianipa@gmail.com
}

\begin{abstract}
The purpose of this research is to find out how the effect implementation of Self Assessment System (SAS), Tax Payer Knowledge (PWP), Service Quality (KP) on Non-employee Personal Taxpayer Compliance at Tax Service Pratama Ciamis (KPP) in 2017. This study uses incidental sampling with a total sample of 99 nonemployee Personal Taxpayers at KPP Pratama Ciamis. The analytical method in this study is descriptive statistical analysis, multiple linear regression analysis, and hypothesis analysis. This study shows that the implementation of SAS, PWP, and KP simultaneous affects the compliance of non-employee individual taxpayers at KPP Pratama Ciamis, and then the results of partial testing show that they are have a positive and significant effect on the compliance of non-employee Personal Taxpayers at KPP Pratama Ciamis.
\end{abstract}

Keywords: Non-employee Personal Taxpayers, Self Assessment System, Service Quality, Taxpayer Knowledge, Taxpayer Compliance

\section{PENDAHULUAN}

Pentingnya pajak telah terbukti di dalam Anggaran Penerimaan dan Belanja Negara (APBN) dimana penerimaan negara paling besar bersumber dari pajak dan sisanya berasal dari Penerimaan Negara Bukan Pajak (PNBP). Upaya untuk meningkatkan perpajakan yang dilakukan oleh pemerintah diharapkan mampu meningkatkan kepatuhan Wajib Pajak yang dapat memicu tingginya tax ratio dalam penerimaan negara, sehingga tax ratio sangat berhubungan dengan kepatuhan Wajib Pajak. Menurut Nurlaela (2017), menyatakan bahwa kepatuhan Wajib Pajak mengenai perpajakan adalah tindakan Wajib Pajak dalam pemenuhan kewajiban perpajakannya sesuai dengan ketentuan peraturan perundang-undangan dan peraturan pelaksanaan perpajakan yang berlaku dalam suatu negara.

Tingkat kepatuhan Wajib Pajak Orang Pribadi non karyawan untuk menunaikan kewajiban pembayaran pajaknya di Indonesia masih cukup rendah. Wakil Menteri Keuangan, Mardyasmo mengakui bahwa setoran pajak Orang Pribadi sejauh ini terlalu rendah terutama Wajib Pajak dari kalangan non karyawan. Hal ini menunjukkan bahwa Wajib Pajak Orang Pribadi seperti pengusaha dan profesi belum memenuhi kewajiban perpajakannya (jogja.tribunnews.com). Rendahnya tingkat kepatuhan Wajib Pajak Orang Pribadi non karyawan dibandingkan dengan Wajib Pajak Orang Pribadi Karyawan, sama hal nya terjadi pada Wajib Pajak Orang Pribadi 
non karyawan yang terdaftar di KPP Pratama Ciamis. Berikut ini tabel mengenai data Kepatuhan Wajib Pajak Orang Pribadi pada KPP Pratama Ciamis yang di mulai dari tahun 2014 sampai dengan tahun 2017.

Tabel 1 Kepatuhan Wajib Pajak Orang Pribadi Pada KPP Pratama Ciamis

\begin{tabular}{cccc}
\hline Tahun & $\begin{array}{c}\text { Persentase } \\
\text { Kepatuhan Wajib } \\
\text { Pajak Orang } \\
\text { Pribadi Karyawan }\end{array}$ & $\begin{array}{c}\text { Persentase } \\
\text { Kepatuhan Wajib } \\
\text { Pajak Orang } \\
\text { Pribadi Non } \\
\text { Karyawan }\end{array}$ & $\begin{array}{c}\text { Selisih Persentase } \\
\text { Kepatuhan Wajib } \\
\text { Pajak Orang pribadi } \\
\text { Karyawan dan Non } \\
\text { Karyawan }\end{array}$ \\
\hline 2014 & $74 \%$ & $12 \%$ & $62 \%$ \\
2015 & $60 \%$ & $24 \%$ & $36 \%$ \\
2016 & $61 \%$ & $26 \%$ & $35 \%$ \\
2017 & $94 \%$ & $41 \%$ & $53 \%$ \\
\hline
\end{tabular}

Sumber: KPP Pratama Ciamis dan data diolah penulis (2018)

Berdasarkan tabel di atas dapat dilihat bahwa tingkat kepatuhan Wajib Pajak Orang Pribadi non karyawan lebih rendah dibandingkan dengan Wajib Pajak Orang Pribadi karyawan. Sehingga dapat diketahui bahwa Wajib Pajak Orang Pribadi non karyawan memiliki tingkat kepatuhan Wajib Pajak yang lebih rendah dibandingkan dengan Wajib Pajak Orang Pribadi Karyawan, hal ini karena masih banyak Wajib Pajak Orang Pribadi non karyawan yang belum melaporkan SPT pajak ke KPP Pratama Ciamis. Kepatuhan perpajakan merupakan suatu bentuk kesediaan pemenuhan kewajiban bagi Wajib Pajak sesuai dengan aturan yang berlaku (Dewi \& Supadmi, 2014). Faktor yang dapat mempengaruhi kepatuhan Wajib Pajak antara lain self assessment system, Pengetahuan Wajib Pajak, dan Kualitas Pelayanan.

Penerapan self assessment system dapat dilaksanakan dengan baik jika masyarakat sudah memahami Undang-Undang Ketentuan Umum dan Tata Cara Perpajakan mengenai tata cara pelaporan, sanksi perpajakan, dan Undang-Undang Pajak Penghasilan atas berbagai penghasilan yang diterima oleh Wajib Pajak. Secara tidak langsung self assessment system telah menuntut Wajib Pajak agar dapat berperan aktif dalam memenuhi kewajiban perpajakannya. Hal ini menimbulkan pembenaran bahwa dalam melaporkan pajak, pembayaran pajak tergantung pada kejujuran dan kepatuhan Wajib Pajak itu sendiri (Dewi \& Supadmi, 2014). Penelitian yang pernah dilakukan oleh Nurlaela (2017), yang menyatakan bahwa self assessment system berpengaruh positif secara signifikan terhadap Kepatuhan Wajib Pajak.

Pentingnya Wajib Pajak mengetahui pengetahuan mengenai pajak diharapkan agar Wajib Pajak menjadi tahu dan memahami bagaimana peran pajak sebagai salah satu sumber penerimaan negara yang akan digunakan untuk membiayai pengeluaran negara yang dapat memberikan kesejahteraan bagi rakyat. Tanpa mempunyai pengetahuan mengenai perpajakan, ada kecenderungan bahwa Wajib Pajak tidak melaksanakan kewajiban untuk mematuhi peraturan perpajakan baik dilakukan secara sengaja maupun tidak sengaja (Sucandra and Supadmi, 2016). Penelitian yang pernah dilakukan oleh Punarbhawa \& Aryani (2013) menyatakan bahwa pengetahuan perpajakan secara signifikan berpengaruh positif terhadap tingkat kepatuhan Wajib Pajak.

Faktor lain yang dapat mempengaruhi kepatuhan Wajib Pajak adalah kualitas pelayanan. Tingkat kepatuhan Wajib pajak dapat ditentukan oleh kualitas pelayanan 
yang diberikan oleh pemerintah. Munculnya kasus yang berhubungan dengan pajak selain merugikan negara juga membuat nilai-nilai pelayanan terhadap masyarakat menjadi menurun dan kurang efektif. Semakin baik kualitas pelayanan yang diberikan oleh pemerintah akan mendorong Wajib Pajak untuk dapat meningkatkan kepatuhan terhadap pajak yang dapat memicu tingginya penerimaan negara. Penelitian yang pernah dilakukan oleh Sucandra \& Supadmi (2016), yang menyatakan bahwa kualitas pelayanan berpengaruh positif dan signifikan pada kepatuhan Wajib Pajak.

Ada pun tujuan dari penelitian ini untuk mengetahui bagaimana pengaruh Penerapan Self Assessment System, Pengetahuan Wajib Pajak, Kualitas Pelayanan terhadap Kepatuhan Wajib Pajak Orang Pribadi non karyawan pada Kantor Pelayanan Pajak (KPP) Pratama Ciamis tahun 2017. Kepatuhan Wajib Pajak perlu ditingkatkan karena dengan semakin banyak Wajib Pajak yang melaksanakan kewajiban perpajakannya dengan baik maka dapat meningkatkan penerimaan negara demi tercapainya kesejahteraan bangsa. Penelitian ini berbeda dengan penelitian sebelumnya karena penelitian ini dilakukan di Kantor Pelayanan Pajak (KPP) Pratama Ciamis dan menjadikan Wajib Pajak Orang Pribadi non karyawan sebagai responden dalam penelitian.

\section{METODE}

Metode penelitian yang digunakan dalam penelitian ini adalah metode kuantitatif yang berdasarkan tujuan penelitian deskriptif. Berdasarkan tipe penyelidikan, penelitian ini bersifat kausal yang artinya penelitian ini dilakukan untuk melihat hubungan variabel terhadap objek yang diteliti lebih bersifat sebab dan akibat. Unit analisis yang digunakan dalam penelitian ini adalah individu, yaitu Wajib Pajak Orang Pribadi non karyawan yang terdaftar di KPP Pratama Ciamis. Berdasarkan waktu pelaksanaan penelitian, dalam penelitian ini menggunakan data cross section.

Pengumpulan data dilakukan melalui kuesioner dengan tipe pernyataan menggunakan skala likert. Sampel yang digunakan dalam penelitian berdasarkan rumus slovin sebanyak 99 responden dari total populasi sebanyak 8.770 Wajib Pajak Orang Pribadi non karyawan di KPP Pratama Ciamis. Jenis teknik sampling yang digunakan adalah insidental. Teknik analisis yang digunakan dalam penelitian ini menggunakan analisis statistik deskriptif, analisis regresi linear berganda dan uji hipotesis.

Tabel 2 Variabel Operasional

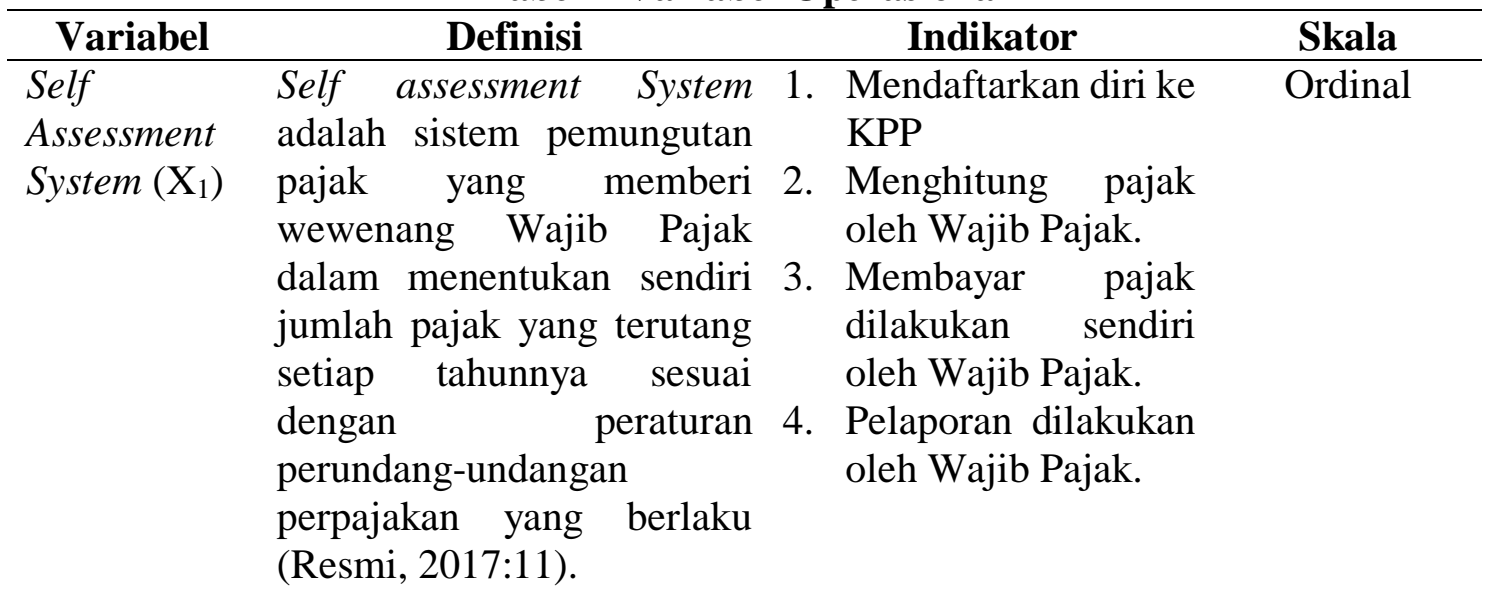




$\begin{array}{ll}\text { Pengetahuan } & \text { Pengetahuan Wajib Pajak } \\ \text { Wajib Pajak } & \text { tentang peraturan } \\ \left(\mathrm{X}_{2}\right) & \text { perpajakan merupakan hasil } \\ & \text { bahwa Wajib Pajak telah } \\ & \text { mengetahui, mengingat dan } \\ & \text { memiliki ilmu mengenai } \\ & \text { peraturan perpajakan yang } \\ & \text { tercantum dalam undang- } \\ & \text { undang perpajakan } \\ & \text { (Punarbhawa and Aryani, } \\ & \text { 2013). }\end{array}$

Kualitas Pelayanan $\left(\mathrm{X}_{3}\right)$
Kualitas pelayanan adalah pelayanan yang dapat memberikan kepuasan kepada Wajib Pajak dan tetap dalam batas memenuhi standar pelayanan yang dapat dipertanggungjawabkan serta harus dilakukan secara terus menerus (Masruroh \& Zulaikha, 2013).
1. Hukum Pajak Materiil.

2. Hukum Pajak Formil.

$$
\text { Formil. }
$$

Ordinal

1. Keandalan

Ordinal (Reliability).

2. Daya Tanggap

(Responsiveness).

3. Jaminan

(Assurance).

4. Empati (Empathy).

5. Bukti Fisik (Tangibles).

Kepatuhan Kepatuhan perpajakan 1. Aspek pelaporan Ordinal Wajib Pajak adalah tindakan Wajib Pajak (Y) dalam pemenuhan kewajiban perpajakannya sesuai dengan ketentuan peraturan perundangundangan dan peraturan pelaksanaan perpajakan yang berlaku dalam suatu negara (Nurlaela, 2017) SPT

2. Aspek income atau penghasilan Wajib Pajak.

3. Aspek law enforcement (pengenaan sanksi).

4. Melaksanakan aspek pembayaran dan pembukuan.

Sumber: Olahan Penulis (2018) 
HASIL DAN PEMBAHASAN

Statistik Deskriptif

Tabel 3 Hasil Statistik Deskriptif

\begin{tabular}{lccccc}
\hline & N & $\begin{array}{c}\text { Nilai } \\
\text { Maksimum }\end{array}$ & $\begin{array}{c}\text { Total } \\
\text { Skor }\end{array}$ & $\begin{array}{c}\text { Persentase } \\
\text { Skor }\end{array}$ & Kategori \\
\hline Self Assessment System & 99 & 4950 & 4167 & $84,18 \%$ & Sangat Baik \\
Pengetahuan Wajib & 99 & 5445 & 4161 & $76,42 \%$ & Baik \\
Pajak & 99 & 5940 & 4657 & $78,40 \%$ & Baik \\
Kualitas Pelayanan & 99 & 5940 & 4695 & $79,04 \%$ & Baik \\
Kepatuhan Wajib & 99 Pajak & &
\end{tabular}

Berdasarkan hasil uji statistik deskriptif menunjukkan bahwa variabel penerapan self assessment system berada pada kategori sangat baik karena persentase yang ditunjukkan berada pada interval $>84 \%$ - 100\%. Sedangkan pada variabel pengetahuan Wajib Pajak, kualitas pelayanan, dan kepatuhan Wajib Pajak berada pada kategori baik karena persentase yang ditunjukkan berada pada interval $>68 \%$ $84 \%$.

\section{Uji Regresi Linier Berganda}

Tabel 4 Hasil Uji Regresi Linier Berganda

\begin{tabular}{|c|c|c|c|}
\hline \multirow[t]{2}{*}{ Model } & \multicolumn{2}{|c|}{$\begin{array}{l}\text { Unstandardized } \\
\text { Coefficients }\end{array}$} & \multirow{2}{*}{$\begin{array}{c}\text { Standardized } \\
\text { Coefficients } \\
\text { Beta }\end{array}$} \\
\hline & B & Std. Error & \\
\hline $1 \quad$ (Constant) &,- 324 & 3,708 & \\
\hline Self Assessment System & ,652 &, 112 & ,491 \\
\hline Pengetahuan Wajib Pajak & ,285 & ,096 & ,246 \\
\hline Kualitas Pelayanan & 176 & 079 & 181 \\
\hline
\end{tabular}

Berdasarkan hasil output didapat nilai persamaan regresi linier berganda sebagai berikut:

$$
Y=-0,324+0,652 S A S+0,285 P W P+0,176 K P+e
$$

Rumus analisis regresi berganda di atas dapat diartikan sebagai berikut:

1. Nilai konstanta sebesar $-0,324$ menunjukkan bahwa jika variabel penerapan self assessment system, pengetahuan Wajib Pajak, dan kualitas pelayanan bernilai 0 , maka nilai kepatuhan Wajib Pajak adalah sebesar -0,324.

2. Nilai koefisien regresi sebesar 0,652 menunjukkan bahwa setiap kenaikan satu satuan variabel penerapan self assessment system, maka kepatuhan Wajib Pajak mengalami kenaikan sebesar 0,572 dengan asumsi variabel independen lainnya bernilai tetap.

3. Nilai koefisien regresi sebesar 0,285 menunjukkan bahwa setiap kenaikan satu satuan variabel pengetahuan Wajib Pajak, maka kepatuhan Wajib Pajak mengalami kenaikan sebesar 0,285 dengan asumsi variabel independen lainnya bernilai tetap.

4. Nilai koefisien regresi sebesar 0,176 menunjukkan bahwa setiap kenaikan satu satuan variabel kualitas pelayanan, maka kepatuhan Wajib Pajak mengalami kenaikan sebesar 0,176 dengan asumsi variabel independen lainnya bernilai tetap. 


\section{Uji Hipotesis}

\section{Pengujian Simultan (Uji F)}

Tabel 5 Hasil Pengujian Simultan (Uji F)

\begin{tabular}{llccccc}
\hline & Model & Sum of Squares & df & $\begin{array}{c}\text { Mean } \\
\text { Square }\end{array}$ & F & Sig. \\
\hline \multirow{2}{*}{1} & Regression & 2481,606 & 3 & 827,202 & 55,876 &, $000^{\mathrm{b}}$ \\
& Residual & 1406,414 & 95 & 14,804 & & \\
& Total & 3888,020 & 98 & & & \\
\hline
\end{tabular}

Berdasarkan hasil pengujian yang terdapat pada tabel diatas diketahui bahwa nilai signifikansi yang diperoleh sebesar 0,000 . Hal tersebut menunjukkan jika nilai signifikansi kurang dari 0,05 sehingga Ha diterima dan $\mathrm{HO}$ ditolak, artinya bahwa penerapan self assessment system, pengetahuan Wajib Pajak, dan kualitas pelayanan secara simultan berpengaruh terhadap kepatuhan Wajib Pajak Orang Pribadi non karyawan di KPP Pratama Ciamis. Dengan demikian semakin baik penerapan self assessment system, pengetahuan Wajib Pajak, dan kualitas pelayanan maka akan semakin baik pula tingkat kepatuhan Wajib Pajak Orang Pribadi non karyawan di KPP Pratama Ciamis.

\section{Koefisien Determinasi}

Tabel 6 Hasil Uji Koefisien Determinasi

\begin{tabular}{ccccc}
\hline Model & $\mathbf{R}$ & $\begin{array}{c}\mathbf{R} \\
\text { Square }\end{array}$ & $\begin{array}{c}\text { Adjusted } \\
\text { R Square }\end{array}$ & $\begin{array}{c}\text { Std. Error of the } \\
\text { Estimate }\end{array}$ \\
\hline 1 &, $799^{\mathrm{a}}$ &, 638 &, 627 & 3,848 \\
\hline
\end{tabular}

Berdasarkan tabel di atas dapat diketahui bahwa nilai Adjusted $R$ Square sebesar 0,627 atau sebesar $62,7 \%$. Hasil ini menunjukkan bahwa kepatuhan Wajib Pajak dipengaruhi sebesar $62,7 \%$ oleh variabel penerapan self assessment system, pengetahuan Wajib Pajak, dan kualitas pelayanan. Sedangkan sisanya 37,3\% dipengaruhi oleh variabel lain selain tiga variabel independen dalam penelitian ini.

\section{Pengujian Parsial (Uji t)}

Tabel 7 Hasil Pengujian Parsial (Uji t)

\begin{tabular}{lccccc}
\hline Model & \multicolumn{2}{c}{$\begin{array}{c}\text { Unstandardized } \\
\text { Coefficients } \\
\text { Std. Error }\end{array}$} & $\begin{array}{c}\text { Standardized } \\
\text { Coefficients } \\
\text { Beta }\end{array}$ & t & Sig. \\
\hline $1 \quad \begin{array}{l}\text { B Constant) } \\
\text { Self Assessment }\end{array}$ &,- 324 & 3,708 & &,- 087 &, 931 \\
$\quad \begin{array}{l}\text { System } \\
\text { Pengetahuan }\end{array}$ &, 652 &, 112 &, 491 & 5,825 &, 000 \\
$\quad \begin{array}{l}\text { Wajib Pajak } \\
\text { Kualitas }\end{array}$ &, 285 &, 096 &, 246 & 2,967 &, 004 \\
$\quad$ Pelayanan &, 176 &, 079 &, 181 & 2,223 &, 029 \\
\hline
\end{tabular}

Berdasarkan hasil pengujian parsial dapat dilihat bahwa setiap variabel independen memiliki nilai signifikansi yang berbeda. Pada variabel penerapan self assessment system memiliki nilai signifikansi 0,000. Hal tersebut menunjukkan nilai signifikansi tersebut kurang dari 0,05, dengan demikian dapat disimpulkan bahwa Ha diterima dan $\mathrm{H} 0$ ditolak yang artinya bahwa penerapan self assessment system secara parsial berpengaruh positif dan signifikan terhadap kepatuhan Wajib Pajak 
Orang Pribadi non karyawan di KPP Pratama Ciamis. Penerapan self assessment system yang sangat baik akan mempermudah Wajib Pajak dalam melaksanakan kewajiban perpajakannya, dimana saat ini Wajib Pajak dituntut untuk berperan aktif dalam menghitung, memperhitungkan, menyetor, dan melaporkan sendiri pajak terutangnya. Adanya kesadaran dan kepatuhan yang dimiliki oleh Wajib Pajak merupakan faktor penting dalam mendukung pelaksanaan sistem tersebut. Apabila sistem ini dilaksanakan dengan baik maka akan menghasilkan tingkat kepatuhan yang semakin baik pula. Hasil penelitian ini sejalan dengan penelitian yang dilakukan oleh Lasmaya \& Fitriani (2017) dan Nurlaela (2017), yang menyatakan bahwa self assessment system memiliki pengaruh positif dan signifikan terhadap kepatuhan Wajib Pajak.

Pada variabel pengetahuan Wajib Pajak memiliki nilai signifikansi 0,004. Hal tersebut menunjukkan nilai signifikansi tersebut kurang dari 0,05, dengan demikian dapat disimpulkan bahwa $\mathrm{Ha}$ diterima dan $\mathrm{HO}$ ditolak yang artinya bahwa pengetahuan Wajib Pajak secara parsial berpengaruh positif dan signifikan terhadap kepatuhan Wajib Pajak Orang Pribadi non karyawan di KPP Pratama Ciamis. Pengetahuan pajak menjadi salah satu elemen penting yang dapat mempengaruhi kepatuhan Wajib Pajak, terutama dalam mendukung penentuan kewajiban perpajakan yang akurat. Pengetahuan dan pemahaman yang lebih baik mengenai peraturan pajak diharapkan mampu untuk memenuhi kewajiban pajak sehingga terciptalah tingkat kepatuhan Wajib Pajak. Hasil penelitian ini sejalan dengan penelitian yang dilakukan oleh Olaoye, Ayeni-Agbaje, \& Alaran-Ajewole (2017) dan Punarbhawa \& Aryani (2013), yang menyatakan bahwa pengetahuan Wajib Pajak berpengaruh positif dan signifikan terhadap kepatuhan Wajib Pajak.

Pada variabel kualitas pelayanan memiliki nilai signifikansi 0,029. Hal tersebut menunjukkan nilai signifikansi tersebut kurang dari 0,05, dengan demikian dapat disimpulkan bahwa Ha diterima dan H0 ditolak yang artinya bahwa kualitas pelayanan secara parsial berpengaruh positif dan signifikan terhadap kepatuhan Wajib Pajak Orang Pribadi non karyawan di KPP Pratama Ciamis. Wajib Pajak yang mendapatkan pelayanan dengan kualitas baik akan senantiasa merasa senang dan puas atas pemberian pelayanan yang diberikan petugas pajak karena Wajib Pajak dapat memperoleh kemudahan dalam menyelesaikan dan melaksanakan seluruh hak dan kewajibannya sebagai Wajib Pajak. Tingkat kepuasan Wajib Pajak yang tinggi akan mendorong pada meningkatnya kepatuhan Wajib Pajak dalam memenuhi kewajiban pajaknya. Hasil penelitian ini sejalan dengan penelitian yang dilakukan oleh Nurhayati, Halimatusadiah, \& Diamonalisa (2015), dan Sucandra \& Supadmi (2016), yang menyatakan bahwa kualitas pelayanan berpengaruh positif dan signifikan terhadap kepatuhan Wajib Pajak.

\section{SIMPULAN}

Berdasarkan hasil penelitian menyimpulkan bahwa penerapan self assessment system, pengetahuan Wajib Pajak, dan kualitas pelayanan secara simultan berpengaruh terhadap kepatuhan Wajib Pajak Orang Pribadi non karyawan di KPP Pratama Ciamis. Penerapan self assessment system secara parsial berpengaruh positif dan signifikan terhadap kepatuhan Wajib Pajak Orang Pribadi non karyawan di KPP Pratama Ciamis. Pengetahuan Wajib Pajak secara parsial berpengaruh positif dan signifikan terhadap kepatuhan Wajib Pajak Orang Pribadi non karyawan di KPP Pratama Ciamis. Kualitas pelayanan secara parsial berpengaruh positif dan signifikan 
terhadap kepatuhan Wajib Pajak Orang Pribadi non karyawan di KPP Pratama Ciamis.

Terdapat beberapa keterbatasan dalam penelitian yaitu sampel yang digunakan hanya 99 responden dan responden dalam penelitian ini hanya Wajib Pajak Orang Pribadi non karyawan sehingga hanya berlaku bagi Wajib Pajak yang melakukan pekerjaan bebas dan memiliki usaha. Hal tersebut karena adanya keterbatasan waktu dan biaya yang dimiliki peneliti. Oleh karena itu diharapkan peneliti selanjutnya dapat memperbanyak jumlah sampel yang akan dijadikan responden dan gunakan semua Wajib Pajak yang terdaftar di Kantor Pelayanan Pajak (KPP) sebagai responden, sehingga penelitian dapat digeneralisasikan dengan baik.

Bagi peneliti selanjutnya yang tertarik untuk melakukan kajian di bidang yang sama, dapat menambah atau memilih variabel independen lain yang tidak digunakan dalam penelitian ini namun memiliki kemungkinan pengaruh terhadap kepatuhan Wajib Pajak. Variabel independen lain yang disarankan adalah sanksi perpajakan, account representative, pemeriksaan pajak, dan sosialisasi perpajakan. KPP Pratama Ciamis diharapkan dapat memberikan penyuluhan baik secara online, offline, atau bahkan dengan keduanya dan memperbaiki tata cara penyampaian saat memberikan konsultasi. Kemudian bagi Wajib Pajak yang masih kurang paham mengenai tata cara perpajakan dapat melakukan konsultasi kepada petugas untuk mendapatkan penjelasan yang mendalam mengenai perpajakan

\section{DAFTAR PUSTAKA}

Dewi, I. C. S. and Supadmi, N. L. (2014) 'Pengaruh Pemeriksaan Pajak, Kesadaran, Kualitas Pelayanan Pada Tingkat Kepatuhan Wajib Pajak Badan', E-Jurnal Akuntansi Universitas Udayana, 9(2), pp. 505-514.

Lasmaya, S. M. and Fitriani, N. N. (2017) 'Pengaruh Self Assesment System Terhadap Kepatuhan Wajib Pajak', Jurnal Computech \& Bisnis, 11(2), pp. 6978.

Masruroh, S. and Zulaikha (2013) 'Pengaruh Kemanfaatan NPWP, Pemahaman Wajib Pajak, Kualitas Pelayanan, Sanksi Perpajakan terhadap Kepatuhan Wajib Pajak (Studi Empiris pada WP OP di Kabupaten Tegal)', Diponegoro Journal of Accounting, 2(4), pp. 435-449.

Nugraha, S. W. (2015) 'Tingkat Kepatuhan Wajib Pajak Perorangan Masih Rendah', Tribunjogja.com [online]. Available at: http://jogja.tribunnews.com/2015/02/09/tingkat-kepatuhan-wajib-pajakperorangan-masih-rendah (Accessed: 28 October 2018).

Nurhayati, N., Halimatusadiah, E. and Diamonalisa (2015) 'Influence of tax officer service quality and knowledge of tax on individual taxpayer compliance in tax office (kpp) Bojonagara Bandung', International Journal of Applied Research, 1(8), pp. 805-809.

Nurlaela, L. (2017) 'Pengaruh Self Assessment System dan Kualitas Pelayanan Pajak terhadap Kepatuhan Wajib Pajak Di KPP Pratama Garut', Jurnal Wacana Ekonomi, 16(3), pp. 001-008.

Olaoye, C. O., Ayeni-Agbaje, A. R. and Alaran-Ajewole, A. P. (2017) 'Tax Information, Administration and Knowledge on Tax Payers' Compliance of Block Moulding Firms in Ekiti State Clement', Journal of Finance and Accounting, 5(4), pp. 131-138.

KPP Pratama Ciamis. 
Punarbhawa, I. G. A. B. and Aryani, N. K. L. (2013) 'Pengaruh Reformasi Administrasi Perpajakan dan Pengetahuan Perpajakan terhadap Tingkat Kepatuhan Pengusaha Kena Pajak (PKP)', E-Jurnal Akuntansi Universitas Udayana, 5(2), pp. 381-397.

Sucandra, L. K. I. P. and Supadmi, N. L. (2016) 'Pengaruh Kualitas Pelayanan, Pemeriksaan Pajak, Pengetahuan Perpajakan dan Sanksi Perpajakan Pada Kepatuhan Wajib Pajak Restoran', E-Jurnal Akuntansi Universitas Udayana, 16(2), pp. 1210-1237. 